\title{
Microbulbifer variabilis sp. nov. and Microbulbifer epialgicus sp. nov., isolated from Pacific marine algae, possess a rod-coccus cell cycle in association with the growth phase
}

Correspondence

Miyuki Nishijima

mnishiji@tecsrg.co.jp

\author{
Miyuki Nishijima, ${ }^{1,2}$ Takahide Takadera, ${ }^{1}$ Nobutaka Imamura, ${ }^{1}$ \\ Hiroaki Kasai, ${ }^{1}$ Kwang-Deuk An, ${ }^{2}$ Kyoko Adachi, ${ }^{1}$ Tomokazu Nagao, ${ }^{1}$ \\ Hiroshi Sano ${ }^{1}$ and Kazuhide Yamasato ${ }^{1,3}$ \\ ${ }^{1}$ Marine Biotechnology Institute, Heita, Kamaishi 026-0001, Japan \\ ${ }^{2}$ TechnoSuruga Laboratory Co. Ltd, Nagasaki, Shimizu-ku, Shizuoka 424-0065, Japan \\ ${ }^{3}$ Department of Fermentation Science, Faculty of Bio-Science, Tokyo University of Agriculture, \\ Sakuragaoka, Setagaya-ku, Tokyo 156-8502, Japan
}

\section{Abbreviation: UVAS, UV-absorbing substance.}

The GenBank/EMBL/DDBJ accession numbers for the 16S rRNA gene sequences of strains $\mathrm{Ni}-2088^{\top}, \mathrm{F}-104^{\top}$ and $\mathrm{C}-38$ are $\mathrm{AB} 167354$, $A B 266054$ and $A B 266055$, respectively, that for the gyrB gene sequence of strain $\mathrm{Ni}-2088^{\top}$ is $A B 276367$ and those for the $f t s Z$ gene sequences of strains $\mathrm{Ni}-2088^{\top}, \mathrm{F}-104^{\top}$, M. hydrolyticus ATCC $700072^{\top}$, M. salipaludis JCM $11542^{\top}$, M. elongatus DSM $6810^{\top}$ and M. maritimus JCM $12187^{\top}$ are AB371302, AB371303, AB371308, AB371307, AB371306 and AB371305, respectively.

Details of strain isolation, a neighbour-joining tree based on concatenated gyrB and fts $Z$ sequences, micrographs of cells of the novel strains and reference strains, fatty acid profiles and a dendrogram based on fatty acid data, 2D TLC of polar lipids of representative novel strains and reference strains and detailed DNA-DNA hybridization results are available as supplementary material with the online version of this paper.
The genus Microbulbifer was described by González et al. (1997) for a biopolymer-decomposing marine gammaproteobacterium, Microbulbifer hydrolyticus. Since then, five species of the genus have been isolated from various marine sources (Yoon et al., 2003a, 2004, 2007; Miyazaki et al., 2008) and one species, the agar-degrading Pseudomonas elongata (Humm, 1946), has been transferred to the genus (Yoon et al., 2003b).

In the course of screening for marine bacteria that produce bioactive substances, we isolated 14 strains that produce anticancer phenazine antibiotics (pelagiomicins; Imamura et al., 1997) and one strain that produces UV-absorbing substances (UVAS; Nagao et al., 2000) from marine algae 
and seagrass collected from tropical Pacific islands and the subtropical Okinawa Prefecture of Japan. Phylogenetically, the isolates belonged to the genus Microbulbifer and were found to possess a clearly discernible cell cycle of rodshaped vegetative cells and resting coccoid cells in association with the growth phase. In this study, we report that this cell cycle is also present in all described Microbulbifer species. Based on phylogenetic affiliation, phenotypic characteristics and genetic distinctness, these bacteria represent two novel species of the genus Microbulbifer.

The sources of the isolates were marine macroalgae (green, red and brown), seagrass and a cyanobacterium collected from coastal areas of the tropical Pacific islands of Palau in 1991, 1994 and 1995 and Yap in 1994, as well as from the island of Ishigaki Jima in Okinawa Prefecture, a subtropical area of Japan, in 1996 (for detailed sources and sites of isolation, see Supplementary Table S1, available in IJSEM Online). Isolation was conducted immediately after collecting the algal samples at the sampling sites. The surface of an alga or seagrass sample was rubbed with a small piece of sterile gauze, which was then soaked in sterilized seawater and shaken vigorously. Aliquots $(100 \mu \mathrm{l})$ of each undiluted sample and of a sample diluted 10-fold with artificial seawater (ASW) (Tropic Marin; Aquarientechnik or Marine Art SF; Osaka-Yakken) were spread onto agar isolation plates. The isolation media used were marine agar 2216 (MA; Difco), 1/10-strength MA (1/10 MA) [3.74 g marine broth $2216(\mathrm{MB})$ powder (Difco), $750 \mathrm{ml}$ ASW, $250 \mathrm{ml}$ distilled water and $15 \mathrm{~g}$ agar, $\mathrm{pH}$ 7.6] and MA amended with 10 p.p.m. polymyxin B and 2 p.p.m. penicillin G. The 14 strains of pelagiomicin-producing bacteria and the single UVAS-producing strain were isolated and subjected to phylogenetic and taxonomic characterization. Microbulbifer hydrolyticus ATCC $700072^{\mathrm{T}}$, Microbulbifer salipaludis JCM $11542^{\mathrm{T}}$, Microbulbifer elongatus ATCC $10144^{\mathrm{T}}$, Microbulbifer maritimus JCM $12187^{\mathrm{T}}$, Microbulbifer celer KCTC $12973^{\mathrm{T}}$, Microbulbifer agarilyticus JCM $14708^{\mathrm{T}}$ and Microbulbifer thermotolerans JCM $14709^{\mathrm{T}}$ were used as reference strains.

PCR amplification of the 16S rRNA gene was performed using bacterial universal primers $8 \mathrm{~F}$ ( $5^{\prime}$-AGAGTTTGATCCTGGCTCAG-3') and B9 (5'-TACGGCTACCTTGTTACGACTT-3'; Hanzawa et al., 1995). PCR products were purified in a QIAquick PCR purification column (Qiagen) and then sequenced with an ABI Big Dye Terminator cycle sequencing ready reaction kit (Applied Biosystems) and an ABI 3700 DNA sequencer (Applied Biosystems). The 16S rRNA gene sequences of the isolates were compared with other sequences in the public databases (GenBank/DDBJ/ EMBL) using BLAST (Altschul et al., 1997). Sequences were aligned with CLUSTAL W (Thompson et al., 1994) and edited with the BioEdit program (Hall, 1999). A phylogenetic tree was constructed by analysing the 16S rRNA gene sequences corresponding to positions 64-1411 (Escherichia coli numbering system) using the software MEGA version 3.0 (Kumar et al., 2004) and the neighbour-joining method
(Saitou \& Nei, 1987). The gyrB gene fragment covering positions $274-1525$ of the E. coli gyrB gene was amplified using deoxyinosine-containing primers UP1Ei (5'-GAAGTCATCACCGTTCTGCAYGSIGGIGGIAARTTYRA-3') and UP2ri (5' -AGCAGGGTACGGATGTGCGAGCCRTCIACRTCIGCRTCIGTCAT- $\left.3^{\prime}\right)$. Sequencing was performed using primers UP1s ( $5^{\prime}$-GAAGTCATCACCGTTCTGCA- $\left.3^{\prime}\right)$ and UP2rs (5'-AGCAGGGTACGGATGTGCGAGCC- $\left.{ }^{\prime}\right)$, as described by Yamamoto \& Harayama (1995). The fragment covering positions 141-1110 of the E. coli ftsZ gene was amplified and sequenced using forward primer $5^{\prime}$ AAYACNGAYGCNCARGCNYT- $3^{\prime}$ and reverse primer $5^{\prime}$ AANGCNGGDATRTCNARRTA-3'. Sequencing and sequence alignment of the $g y r B$ and $f t s Z$ genes were performed as described for the $16 \mathrm{~S}$ rRNA gene. A phylogenetic tree based on the concatenated dataset of $g y r B$ and $f t s Z$ gene sequences was constructed in the same way. The reliability of cluster formation was assessed by a bootstrap analysis based on 1000 resamplings of the dataset (Felsenstein, 1985). Accession numbers of the reference strains used in the phylogenetic analysis are given in Fig. 1 and Supplementary Fig. S1.

Almost-complete 16S rRNA gene sequences were determined for strains $\mathrm{Ni}-2088^{\mathrm{T}}, \mathrm{C}-38$ (a pelagiomicin-producing strain) and $\mathrm{F}-104^{\mathrm{T}}$. A comparison against $16 \mathrm{~S}$ rRNA gene sequences available in DNA databases indicated that the isolates belonged to the class Gammaproteobacteria (Fig. 1). The degree of sequence similarity between strains $\mathrm{Ni}-2088^{\mathrm{T}}$ and $\mathrm{C}-38$ was $99.9 \%$, and the respective values for strain $\mathrm{F}-104^{\mathrm{T}}$ to strains $\mathrm{Ni}-2088^{\mathrm{T}}$ and $\mathrm{C}-38$ were 99.3 and $99.2 \%$. Among genera with validly published names, the sequences most closely associated with these strains were those of the genus Microbulbifer, which comprises seven species: M. hydrolyticus (the type species; González et al., 1997), M. salipaludis (Yoon et al., 2003a), M. elongatus (formally Pseudomonas elongata; Humm, 1946; Yoon et al., 2003b), M. maritimus (Yoon et al., 2004), M. celer (Yoon et al., 2007), M. agarilyticus (Miyazaki et al., 2008) and $M$. thermotolerans (Miyazaki et al., 2008). The respective degrees of sequence similarity of strains $\mathrm{Ni}-2088^{\mathrm{T}}$ and $\mathrm{F}-$ $104^{\mathrm{T}}$ to the type strain of $M$. hydrolyticus were 94.9 and $94.5 \%$. The isolates formed a phylogenetic cluster with the type strains of M. maritimus and M. thermotolerans with a bootstrap value of $100 \%$, while the remaining Microbulbifer species formed a separate cluster, also with a bootstrap value of $100 \%$ (Fig. 1). Other aerobic marine genera in the class Gammaproteobacteria, including the next closest relative Saccharophagus, were more distantly related (sequence similarity <91\%). Phylogenetic analysis of the concatenated sequences of the gyrB and $f t s Z$ genes gave two separate clusters composed of the novel isolates and three Microbulbifer species, with respective bootstrap support of 100 and $98 \%$. M. maritimus formed part of the cluster formed by the Microbulbifer species, but with low bootstrap support (Supplementary Fig. S1). Analysis of gyrB gene sequences gave a phylogenetic tree with topology similar 


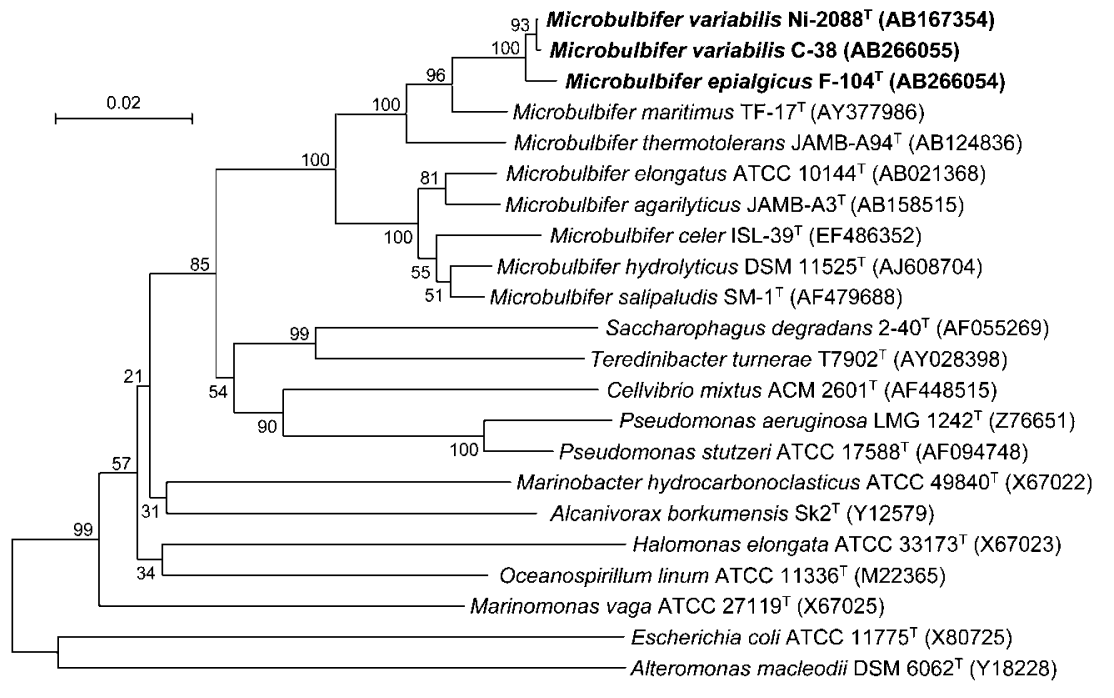

Fig. 1. Phylogenetic affiliation of Microbulbifer variabilis sp. nov. strains $\mathrm{Ni}-2088^{\top}$ and $\mathrm{C}-38$ and Microbulbifer epialgicus sp. nov. $\mathrm{F}-104^{\top}$ based on 16S rRNA gene sequences. The tree, which was constructed using the neighbour-joining method, is based on a comparison of approximately 1350 nucleotides. Bootstrap values, expressed as percentages of 1000 replications, are provided at branch points. Bar, 0.02 substitutions per nucleotide position. to that given by the analysis of the concatenated $\operatorname{gyr} B$ and $f t s Z$ sequences (not shown).

Cultural characteristics were observed for colonies grown on MA and 1/10 MA plates. The morphology of rod and coccoid cells was observed mainly for cultures grown on 1/ $10 \mathrm{MA}$ ( $1.5 \%$ agar or agarose; Agarose S, Wako Chemicals) at 20 and $24{ }^{\circ} \mathrm{C}$ using a slide culture technique. An agar medium film (about $0.25 \mathrm{~mm}$ thick) was prepared by pouring a small amount of molten 1/10 MA onto a sterile glass slide. The agar medium film was spot-inoculated, and the slides were placed on 1/10 MA in a Petri dish, which was then sealed with tape to prevent evaporation of water during incubation. After growth, a small drop of $75 \%$ ASW was added to the microcolony, which was covered with a coverslip. The peripheral portion of the growth was observed by phase-contrast light microscopy. Cells were released from the microcolony into the $75 \%$ ASW, adhered to the surface of the agar medium film following release or remained at the periphery. Coccoid cells were observed by scanning electron microscopy as well as by optical microscopy. They were then taken from the microcolony, which had formed on 1/10 MA for 4 days at $24{ }^{\circ} \mathrm{C}$, and fixed with $2.5 \%$ glutaraldehyde (pre-fixation) and $2 \%$ osmium tetroxide (post-fixation). Following dehydration in an ethanol series, the samples were dried to the critical point in $\mathrm{CO}_{2}$ and coated with platinum-palladium. Prepared specimens were viewed using an S-2500 scanning electron microscope (Hitachi). Fibrous structures on the rod cells were observed with an H-7000 transmission electron microscope (Hitachi) for cells grown in MA and negatively stained with uranyl acetate.

Conventional taxonomic features were determined according to the procedures described by Cowan and revised by Barrow \& Feltham (1993), except that all media used were supplemented with $3 \%(\mathrm{w} / \mathrm{v}) \mathrm{NaCl}$ or prepared with $75 \%$ ASW. Incubation was at $30{ }^{\circ} \mathrm{C}$ unless otherwise noted. The production of acid from glucose and growth under aerobic and anaerobic conditions was examined in BBL phenol red broth base (Difco) prepared with $75 \%$ ASW and with $1 \%$ $(w / v)$ glucose added. The use of ammoniacal nitrogen and growth factor requirements were evaluated by observing growth in marine salts basal medium (BM) described by Baumann \& Baumann (1981) supplemented with $0.2 \%$ glucose. The use of carbohydrates, related compounds, organic acids and amino acids was determined using BM supplemented with the following vitamins $\left(\mathrm{mg} \mathrm{l}^{-1}\right)$ : riboflavin (2), pyridoxine hydrochloride (4), pyridoxal hydrochloride (4), p-aminobenzoic acid (2), calcium pantothenate (2), niacin (2), folic acid (0.8), nicotinic acid (0.8), thiamine hydrochloride (2) and biotin (0.01). Each carbon compound was added at a concentration of $0.2 \%$ $(\mathrm{w} / \mathrm{v})$. Tests for urease, $\beta$-galactosidase (PNPG), indole production, arginine dihydrolase and aesculin hydrolysis were conducted using the API 20NE system (bioMérieux). In addition, API ZYM tests were conducted to examine enzyme activities. Both test kits were used as described in the manufacturer's manual, except that cells for inoculation were suspended in $75 \%$ ASW. Incubation time in the API ZYM tests was extended to $24 \mathrm{~h}$, which gave reliable results. $\mathrm{MB}$ was used to study growth responses to temperature and $\mathrm{pH}$. For the $\mathrm{pH}$ experiment, $\mathrm{MB}$ was supplemented with Good's buffers (MES, Tris, MOPS, HEPES, EPPS, CHES and CAPS; Dojin) at a concentration of $0.1 \mathrm{M}$ each. To determine the requirements for $\mathrm{Na}^{+}, \mathrm{Mg}^{2+}$ and $\mathrm{Ca}^{2+}$, a peptone-yeast extract-glucose medium was used as a base containing $5 \mathrm{~g}$ Bacto peptone (Difco), $1 \mathrm{~g}$ Bacto yeast extract (Difco), $10 \mathrm{~g}$ glucose, $0.1 \mathrm{~g}$ ferric citrate, $5.9 \mathrm{~g}$ $\mathrm{MgCl}_{2} \cdot 7 \mathrm{H}_{2} \mathrm{O}$ and $1.8 \mathrm{~g} \mathrm{CaCl}_{2} \cdot 2 \mathrm{H}_{2} \mathrm{O}$ in $1 \mathrm{l}$ distilled water at $\mathrm{pH}$ 7.6. Growth, if any, was observed with or without either $2 \%(\mathrm{w} / \mathrm{v}) \mathrm{NaCl}$ or equimolar $\mathrm{KCl}$ to examine $\mathrm{Na}^{+}$ requirement and with $2 \%(\mathrm{w} / \mathrm{v}) \mathrm{NaCl}$ added with $\mathrm{MgCl}_{2}$, $\mathrm{CaCl}_{2}$ or both omitted to examine requirements for $\mathrm{Ca}^{2+}$ and/or $\mathrm{Mg}^{2+}$. The dependence of growth initiation on $\mathrm{NaCl}$ concentration was investigated with the basal medium supplemented with $0-10 \% \mathrm{NaCl}(\mathrm{w} / \mathrm{v})$ at $0.5 \%$ intervals. 


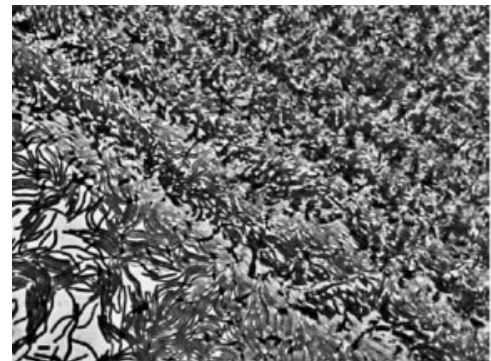

(a)

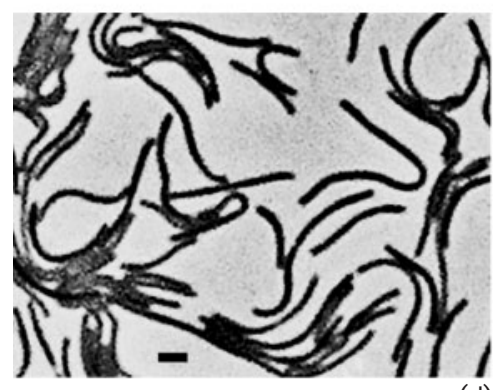

(d)

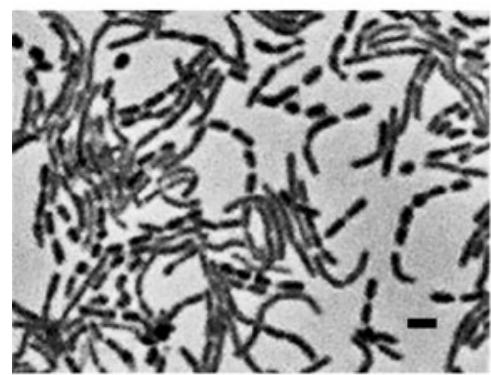

(g)
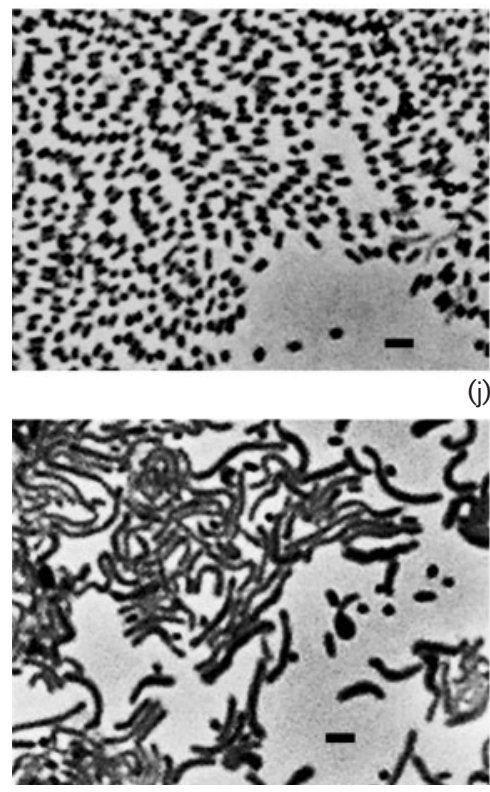

(m)

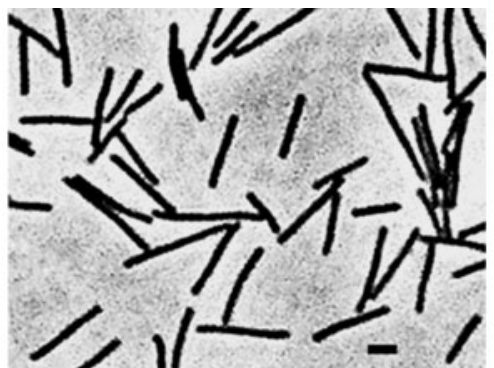

(b)
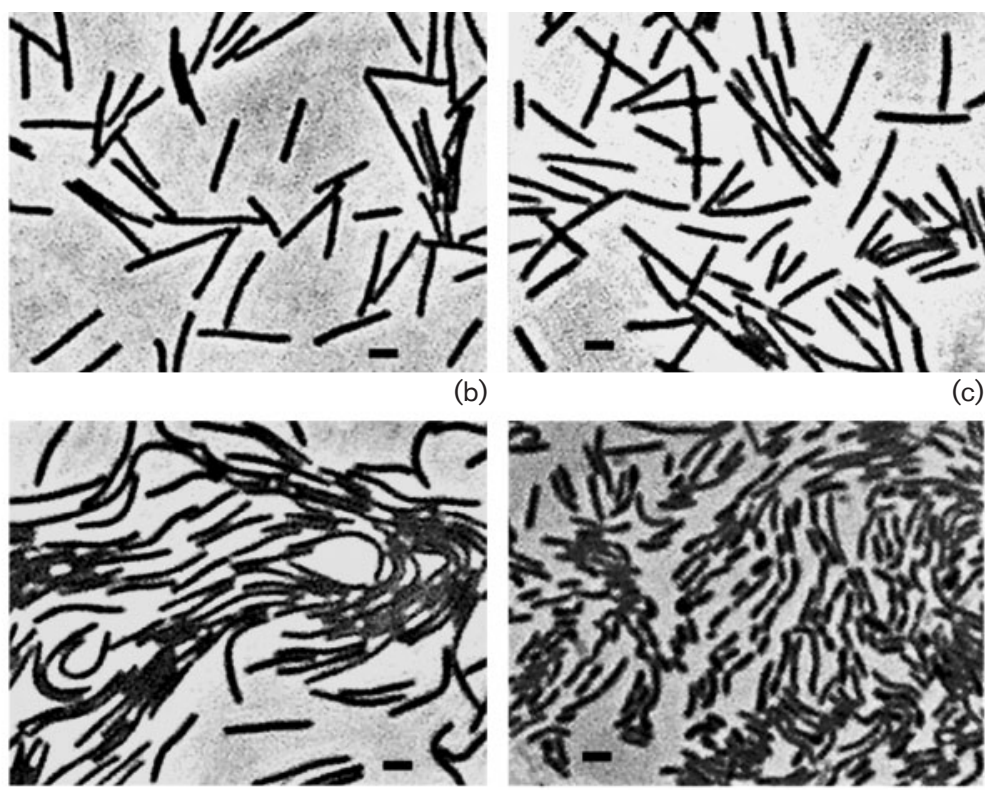

(e)
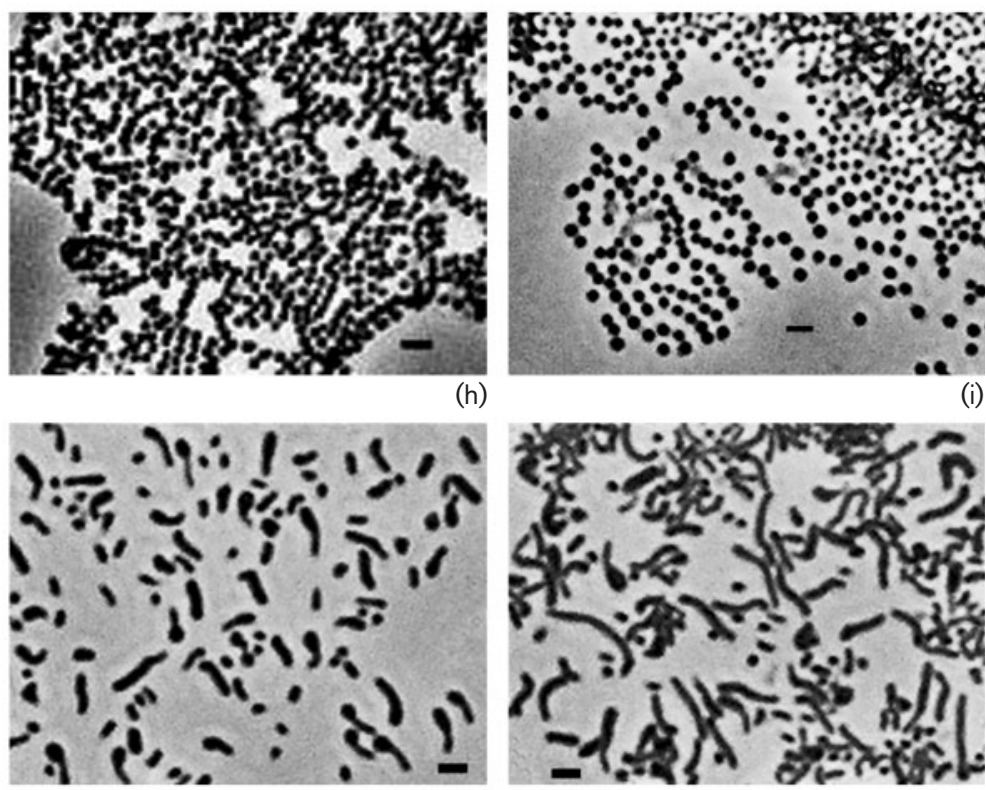

(k)
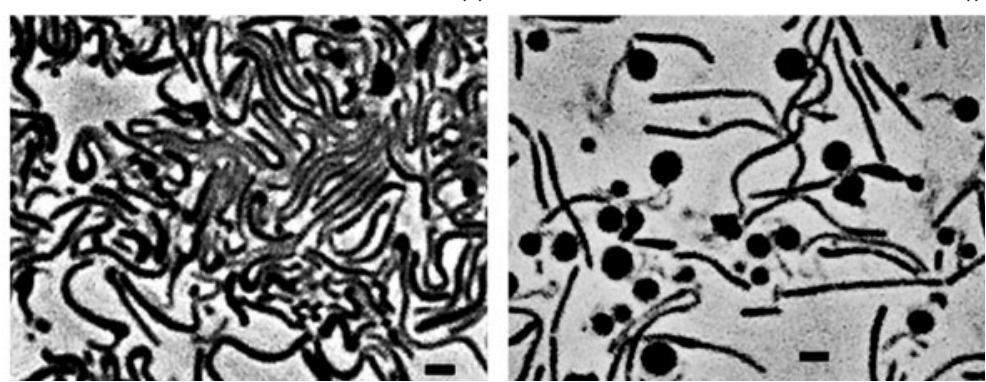

(n) (c)

\section{政}


Fig. 2. Phase-contrast micrographs of cells of $M$. variabilis sp. nov. Ni-2088 ${ }^{\top}$ and $M$. epialgicus sp. nov. $\mathrm{F}-104^{\top}$. The cells were grown on an agar film of $1 / 10 \mathrm{MA}$ on a glass slide in a moist chamber at $24{ }^{\circ} \mathrm{C}$, unless otherwise stated, and were prepared for observation using a drop of $75 \%(\mathrm{v} / \mathrm{v})$ ASW and a coverslip over the periphery of the microcolony. Bars, $2 \mu \mathrm{m}$. (a) Peripheral portion of a microcolony of strain $\mathrm{F}-104^{\top}$ incubated for 2 days at $24{ }^{\circ} \mathrm{C}$, showing terracing of six or seven rows of rod cells. (b, c) Straight rod cells of strains Ni-2088 ${ }^{\top}$ (b) and $\mathrm{F}-104^{\top}$ (c); the cells, grown for $43 \mathrm{~h}$, were released into $75 \%$ ASW. (d, e) Curved and bent rod cells of strains Ni-2088 ${ }^{\top}$ (d) and F-104 $4^{\top}$ (e); the cells, grown at $20{ }^{\circ} \mathrm{C}$ for 2 days and at $24^{\circ} \mathrm{C}$ for $24 \mathrm{~h}$, respectively, were released into $75 \% \mathrm{ASW}$ and adhered to the surface of an agar medium film. (f, g) Micrographs showing the process of conversion of rod cells to coccoid cells of strain $\mathrm{Ni}^{-2088^{\top}}$ through successive division and probable simultaneous fragmentation. The cells were grown for 2 days at $20^{\circ} \mathrm{C}$ (f) and 3 days at $24^{\circ} \mathrm{C}(\mathrm{g})$. (h, i) Coccoid cells of strains Ni-2088 ${ }^{\top}$ (h) and $\mathrm{F}-104^{\top}$ (i) from a microcolony incubated for 7 days. (j) Ovoid cells of strain $\mathrm{Ni}-2088^{\top}$ from a microcolony incubated for 7 days. $(k-n)$ Micrographs showing reversion of coccoid cells to rod cells of strain $\mathrm{Ni}-2088^{\top}$. Coccoid cells were incubated for $7,9,12$ and $24 \mathrm{~h}$, respectively. (o) Spherical bodies of strain Ni-2088 ${ }^{\mathrm{T}}$. The growth was incubated for 2 days, covered with a coverslip after adding a drop of $75 \%$ ASW and incubated for a further $24 \mathrm{~h}$.

cells, with approximately $6-12 \mu \mathrm{m}$ between each row (Fig. 2a). Each row of rod cells seemed to constitute the edge of a 'sheet of rod cells' formed by the arrangement of cells in a single horizontal plane. The cells were rod-shaped at the periphery of growing colonies and were coccoidovoid in the inner portion of colonies incubated for 2 days or more on 1/10 MA and 2-3 days or more on MA at $24{ }^{\circ} \mathrm{C}$. The rod cells were very flexible and elastic; cells released from the periphery of growth into $75 \%$ ASW were straight and slender (Fig. 2b, c), whereas those that were released and adhered to the agar medium surface were curved and bent to various degrees (Fig. 2d, e). Nuclear staining with a fluorescent dye $\left(4^{\prime}, 6\right.$-diamidino-2-phenylindole) revealed that the rod cells were multinucleate (not shown). The rod cells of both $\mathrm{Ni}-2088^{\mathrm{T}}$ and $\mathrm{F}-104^{\mathrm{T}}$ possessed peritrichous appendages of a fine fibrous nature on the cell surface (Fig. 3). Because all strains were isolated from the surfaces of marine algae and seagrass, the peritrichous fibrous structures on the cell surface could play a role in attachment of the cells to the surface of marine algae. Romanenko et al. (2003) hypothesized that external fibril-like structures on cells of Oceanisphaera

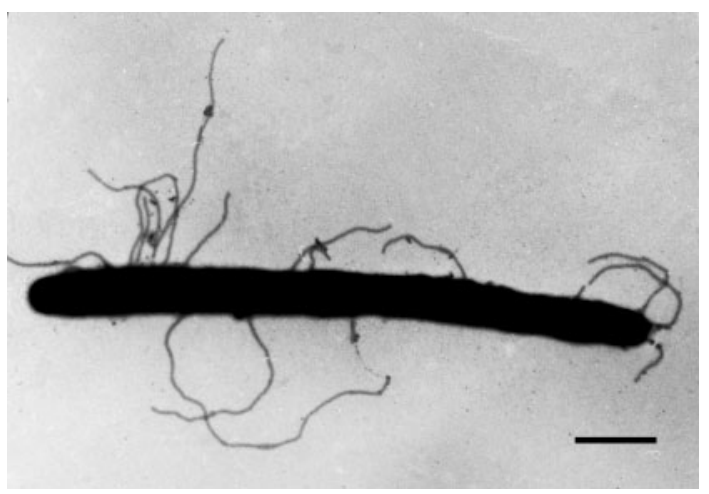

Fig. 3. Transmission electron micrograph of a negatively stained rod cell of $M$. variabilis sp. nov. $\mathrm{Ni}-2088^{\top}$ possessing peritrichous fibrous appendages on the cell surface. The cell was taken from a culture grown on MA at $30{ }^{\circ} \mathrm{C}$ for $24 \mathrm{~h}$. Bar, $1 \mu \mathrm{m}$. litoralis might be an adaptation to enable attachment to the surfaces of marine sand sediment. The coccoid-ovoid cells were optically much denser than the rod cells and had coarse surfaces, which might play a role in attachment to fresh materials when drifting in seawater (Fig. 4).

All the isolates were aerobic, catalase- and oxidase-positive, mesophilic, neutrophilic and slightly halophilic. Strains Ni$2088^{\mathrm{T}}$ and $\mathrm{F}-104^{\mathrm{T}}$ both required $\mathrm{Na}^{+}$, which could not be replaced by $\mathrm{K}^{+}$. The isolates grew in peptone-yeast extractglucose medium containing $2.0 \% \mathrm{NaCl}$ in the presence of either $\mathrm{Mg}^{2+}$ or $\mathrm{Ca}^{2+}$, but they could not grow in the absence of both. The isolates grew in BM with added glucose, were capable of using ammoniacal nitrogen as a

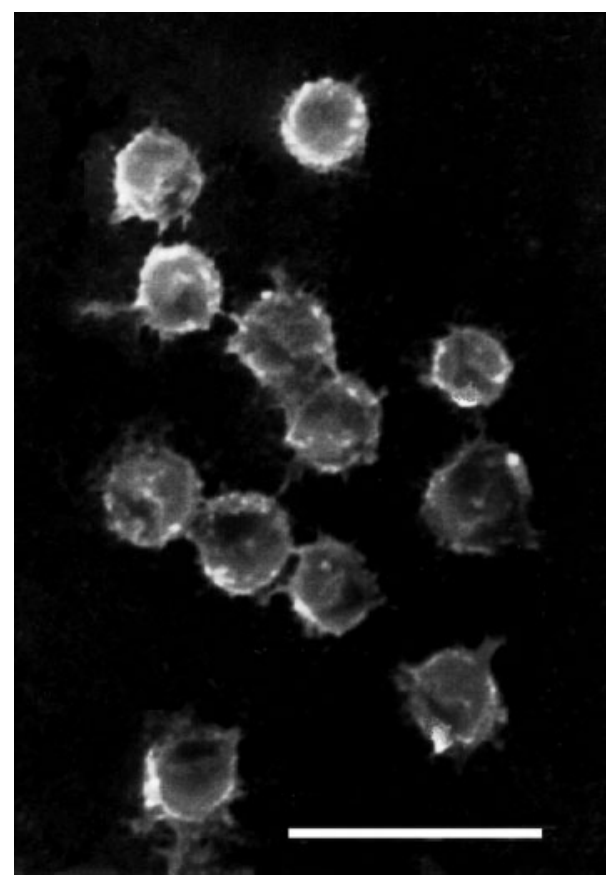

Fig. 4. Scanning electron micrograph of coccoid cells of $M$. epialgicus sp. nov. F-104 $4^{\top}$. The cells were taken from a culture grown on $1 / 10 \mathrm{MA}$ at $24^{\circ} \mathrm{C}$ for 4 days. Bar, $2.5 \mu \mathrm{m}$. 
nitrogen source and did not require growth factors. The range of compounds used as sole carbon sources was limited. Assimilation profiles of 36 compounds tested were almost identical for all the isolates, with differences between the pelagiomicin-producing strains and UVASproducing strain $\mathrm{F}-104^{\mathrm{T}}$ in acetate and $\mathrm{L}$-arginine assimilation. Additional and more detailed taxonomic features are given in Table 1 and in the species descriptions.

The cells exhibited a clearly discernible cycle of rod and coccoid-ovoid cells in association with the growth phase. The conversion of rods to coccoid cells and the reversion of coccoid cells to rods was followed by the slide culture technique on $1 / 10 \mathrm{MA}$ at $24{ }^{\circ} \mathrm{C}$. The ability of coccoid cells to survive for extended periods was examined for cells taken from the inner to central portion of colonies on a 1/ 10 MA plate, which had been sealed with tape to prevent drying and maintained at room temperature $\left(23-27^{\circ} \mathrm{C}\right)$ for up to 14 months for the novel isolates and 4 months for Microbulbifer reference strains. Viability of the isolates was examined by spreading a loopful of cells on a 1/10 MA plate and incubating at $25{ }^{\circ} \mathrm{C}$ for $5-7$ days. For the Microbulbifer reference strains, cells were suspended in $2 \mathrm{ml} \mathrm{1/10} \mathrm{MB}$ and treated at 50 or $55{ }^{\circ} \mathrm{C}$, depending on the strain, to kill rod cells that might not have converted to coccoid cells and could still be viable. To examine the heat resistance of rod cells, $100 \mu \mathrm{l}$ of a young culture in $1 / 10 \mathrm{MB}$ was added to $2 \mathrm{ml}$ semi-solid $1 / 10 \mathrm{MA}(0.2 \%$ agar, w/v) in a test tube that had been pre-equilibrated to the test temperature. The cell suspensions were held at test temperatures of 45 to $65{ }^{\circ} \mathrm{C}$ at intervals of $5{ }^{\circ} \mathrm{C}$. The heat resistance of coccoid cells was examined as for the rods, except that a loopful of cells was taken from a culture on a $1 / 10$ MA plate grown and kept at $23-27{ }^{\circ} \mathrm{C}$ for $2-4$ weeks followed by heat treatment at $45-80{ }^{\circ} \mathrm{C}$ for $10 \mathrm{~min}$. For the Microbulbifer reference strains, cells were suspended in 1/10 $\mathrm{MB}$ instead of a semi-solid agar medium and, after heat treatment, $50 \mu \mathrm{l}$ of each cell suspension was spread on $1 / 10$ MA. The inoculated media were incubated at $25{ }^{\circ} \mathrm{C}$ for $5-$ 7 days to monitor the occurrence of colonies in the semisolid agar medium or on agar medium plates.

The long rod cells observed during the growth phase converted to coccoid-ovoid cells when proliferation ceased. Just inside the periphery of a microcolony on $1 /$ $10 \mathrm{MA}$ in slide culture incubated for 2-3 days, almost all the cells were of a coccoid-ovoid form. The conversion of rod cells to coccoid-ovoid cells occurred through a process of successive division and a probable simultaneous fragmentation (Fig. 2f, g), with subsequent rounding of each unit to form coccoid-ovoid cells (Fig. $2 \mathrm{~h}-\mathrm{j}$ ). The coccoid cells were arranged in orderly chains, with a faint track of rod cells between the adjacent cells. The coccoid cells in the chain probably adhered to the adjacent cells. The chains of coccoid cells also probably adhered to adjacent chains on a single horizontal plane, thus forming a 'sheet of coccoid cells' (Fig. $2 \mathrm{~h}-\mathrm{j}$ and Supplementary Figs S3c-g and S4). Some sheets of coccoid cells remained at the periphery of the microcolony and others were released from it and floated in the $75 \%$ ASW. Supplementary Fig. S2(a, b) shows two sheets of coccoid cells floating in $75 \%$ ASW with different depths of focus under a microscope with their peripheries at right angles. Nearly all the rod cells had converted to coccoid-ovoid cells. The coccoid cells reverted to a rod form when transferred to fresh medium. The outgrowth of rods from the coccoid cells occurred after incubation for 6-7 h (Fig. 2k), and they grew vigorously to become long and curved/bent rod cells within $24 \mathrm{~h}$ (Fig. 2l-n), thus completing a rod-coccus cell cycle. Coccoid cells were similarly formed on $75 \%$ ASW agar containing $0.05 \%(\mathrm{w} / \mathrm{v})$ glucose and $0.05 \%(\mathrm{w} / \mathrm{v})$ $\mathrm{NH}_{4} \mathrm{Cl}$ but no other organic nutrient. Dramatic conversion from rod to coccoid cells was observed when cells grown in $\mathrm{MB}$ at $13{ }^{\circ} \mathrm{C}$ for 7 days with shaking were transferred to $30{ }^{\circ} \mathrm{C}$ : the rod cells, which had been very long to filamentous (up to $50 \mu \mathrm{m}$ long), converted into coccoid cells within $24 \mathrm{~h}$. The type strains of all seven described species of Microbulbifer also exhibited a rod-coccus cell cycle in association with the growth phase, which was identical to that of the isolates. Micrographs of coccoidovoid cells of the Microbulbifer reference strains are presented in Supplementary Fig. S3(c-g). The outgrowth of rods from coccoid cells of $M$. hydrolyticus ATCC $700072^{\mathrm{T}}$ is shown in Supplementary Fig. S3(h).

The presence of a rod-coccus cell cycle as observed here has not been described previously for Microbulbifer species (Humm, 1946; González et al., 1997; Yoon et al., 2003a, 2004, 2007; Miyazaki et al., 2008). While the presence of coccoid cells has been described in M. elongatus (Humm, 1946; Palleroni, 1984; Yoon et al., 2003b), M. agarilyticus (Miyazaki et al., 2008) and M. thermotolerans (Miyazaki et al., 2008), features of the coccoid cells have not. The processes of formation and germination of coccoid-ovoid cells in the present isolates apparently differ from those in various Gram-negative bacteria, including Azotobacter cysts (Sadoff, 1975), Azospirillum cysts (Sadasivan \& Neyra, 1985, 1987), Myxococcus myxospores (Dworkin, 1996; Reichenbach \& Dworkin, 1992), Azotobacter-type cysts, exospores and lipid cysts of methanotrophs (Whittenbury et al., 1970), Sporocytophaga microcysts (Reichenbach, 1992), Rhodocista cysts (Berleman \& Bauer, 2004; Kawasaki et al., 1992), Bdellovibrio bdellocysts (Hoeniger et al., 1972; Tudor \& Conti, 1977) and Ramlibacter cysts (Heulin et al., 2003). The resting coccoid cells of the novel isolates could not be regarded as cysts, since shedding of the cyst coat was not observed upon germination (Fig. $2 k, 1$ ).

The coccoid cells of the isolates formed on 1/10 MA plates were viable after being kept at room temperature (23$27{ }^{\circ} \mathrm{C}$ ) for at least 14 months. In these old plate cultures, some coccoid cells remained optically dense, but the majority became optically faint as 'ghost cells' (Supplementary Fig. S4). For most of the 1/10 MA plate cultures examined, coccoid cells treated at $55{ }^{\circ} \mathrm{C}(\mathrm{Ni}-$ $\left.2088^{\mathrm{T}}\right)$ or $50{ }^{\circ} \mathrm{C}\left(\mathrm{F}-104^{\mathrm{T}}\right)$ prior to spreading on a $1 / 10 \mathrm{MA}$ plate (for procedure, see the description of the heat resistance of rod cells) were not able to form colonies 
Table 1. Differential phenotypic characteristics of strains $\mathrm{Ni}-2088^{\top}$ and $\mathrm{F}-104^{\top}$ and the seven described Microbulbifer species

Taxa: 1, M. variabilis sp. nov. Ni-2088 ${ }^{\mathrm{T}}$; 2, M. epialgicus sp. nov. F-104 ${ }^{\mathrm{T}}$; 3, M. hydrolyticus (unless indicated, data from González et al., 1997); 4, M. salipaludis (Yoon et al., 2003a); 5, M. elongatus (Humm, 1946); 6, M. maritimus (Yoon et al., 2004); 7, M. celer (Yoon et al., 2007); 8, M. agarilyticus (Miyazaki et al., 2008); 9, M. thermotolerans (Miyazaki et al., 2008). +, Positive; -, negative; W, weakly positive; ND, no data.

\begin{tabular}{|c|c|c|c|c|c|c|c|c|c|}
\hline Characteristic & 1 & 2 & 3 & 4 & 5 & 6 & 7 & 8 & 9 \\
\hline Pigmentation & $\begin{array}{l}\text { Cream (young colonies), yel- } \\
\text { lowish green (diffusible) }\end{array}$ & Yellowish brown & Cream & Greyish yellow & $\begin{array}{l}\text { Yellowish brown } \\
\text { (diffusible) }\end{array}$ & Yellowish brown & Greyish yellow & Cream & Brown \\
\hline Morphology & Rods-cocci & Rods-cocci & Rods-cocci* & Rods-cocci ${ }^{*}$ & Rods-cocci* ${ }^{\star}$ & Rods-cocci* & Rods-cocci ${ }^{*}$ & Rods-cocci* & Rods-cocci* \\
\hline Resting coccoid cells & + & + & $t^{*}$ & $t^{\star}$ & $t^{*}$ & $t^{*}$ & $t^{*}$ & $t^{*}$ & $t^{*}$ \\
\hline Motility & - & - & - & - & + & - & $t^{*}$ & - & + \\
\hline Nitrate reduction & + & + & $-{ }^{*}$ & $+^{*}$ & $-*$ & $+^{*}$ & - & + & + \\
\hline \multicolumn{10}{|l|}{$\begin{array}{l}\text { Temperature for growth } \\
\left({ }^{\circ} \mathrm{C}\right)\end{array}$} \\
\hline Optimum & 30 & 30 & 37 & 37 & $25-30,34^{a} \dagger$ & 37 & ND & $31-35$ & $43-49$ \\
\hline Maximum & 42 & 40 & 41 & 45 & $38^{a}$ & 48 & 48 & $35-38$ & $52-54$ \\
\hline Growth at $10 \% \mathrm{NaCl}$ & - & - & - & + & $-{ }^{a}$ & + & + & - & - \\
\hline Aesculin hydrolysis & + & - & $+^{b}$ & $--^{a}$ & $+{ }^{a}$ & - & + & - & + \\
\hline Agarase & - & - & - & $\mathrm{w}$ & + & - & - & + & + \\
\hline Cellulase & - & - & + & + & + & $\mathrm{ND}$ & $\mathrm{ND}$ & $\mathrm{ND}$ & $\mathrm{ND}$ \\
\hline Chitinase & - & - & + & - & + & - & ND & + & + \\
\hline Lecithinase & + & + & $-*$ & $-*$ & $-*$ & $-*$ & $\mathrm{ND}$ & $\mathrm{ND}$ & $\mathrm{ND}$ \\
\hline \multicolumn{10}{|l|}{ Utilization of: } \\
\hline Glucose & + & + & + & $\mathrm{ND}$ & + & + & - & + & + \\
\hline Acetate & + & - & + & ND & + & + & + & ND & ND \\
\hline Malate & - & - & + & $\mathrm{ND}$ & + & + & - & $\mathrm{ND}$ & $\mathrm{ND}$ \\
\hline Succinate & - & - & + & $\mathrm{ND}$ & + & + & - & $\mathrm{ND}$ & $\mathrm{ND}$ \\
\hline Glutamate & + & + & + & ND & + & - & - & ND & ND \\
\hline \multicolumn{10}{|l|}{ API ZYM tests $\ddagger$} \\
\hline Trypsin & + & + & $-*$ & $-*$ & $-*$ & $-*$ & $-*$ & $-*$ & $-*$ \\
\hline$\alpha$-Mannosidase & - & + & $-*$ & $-*$ & $-*$ & $-*$ & $-^{*}$ & $-*$ & $-{ }^{*}$ \\
\hline$\alpha$-Glucosidase & + & + & $+^{\star}$ & $\mathrm{w}^{*}$ & $\mathrm{w}^{*}$ & $\mathrm{~W}^{*}$ & $-{ }^{*}$ & $-^{*}$ & $-{ }^{*}$ \\
\hline $\begin{array}{l}N \text {-Acetyl- } \beta \text {-glucosami- } \\
\text { nidase }\end{array}$ & - & - & $-{ }^{*}$ & $+^{*}$ & $-*$ & $-*$ & $-^{*}$ & $-^{*}$ & $+^{*}$ \\
\hline $\begin{array}{l}\mathrm{Ca}^{2+} \text { or } \mathrm{Mg}^{2+} \text { require- } \\
\text { ment }\end{array}$ & + & + & $-^{*}$ & $-*$ & $-*$ & $-*$ & ND & $\mathrm{ND}$ & $\mathrm{ND}$ \\
\hline $\begin{array}{l}\text { Major fatty acid(s) } \\
\text { (approx. }>15 \% \text { ) }\end{array}$ & $\mathrm{C}_{18: 1} \omega 7 c, \mathrm{C}_{16: 0}$ & $\mathrm{C}_{18: 1} \omega 7 c, \mathrm{C}_{16: 0}$ & iso- $\mathrm{C}_{15: 0^{*}}$ & $\begin{array}{c}\mathrm{C}_{18: 1} \omega 7 c, \text { iso- } \\
\mathrm{C}_{15: 0}, \text { iso- } \\
\mathrm{C}_{17: 1} \omega 9 c^{\star}\end{array}$ & $\begin{array}{l}\mathrm{C}_{18: 1} \omega 7 c \\
\text { iso- } \mathrm{C}_{15: 0^{*}}\end{array}$ & $\begin{array}{c}\mathrm{C}_{18: 1} \omega 7 c, \text { iso- } \\
\mathrm{C}_{15: 0}, \text { iso- } \\
\mathrm{C}_{17: 1} \omega 9 c^{\star}\end{array}$ & iso- $\mathrm{C}_{15: 0^{*}}$ & $\begin{array}{l}\mathrm{C}_{18: 1} \omega 7 c, \\
\text { iso- } \mathrm{C}_{15: 0^{*}}\end{array}$ & $\begin{array}{l}\mathrm{C}_{18: 1} \omega 7 c \text {, iso- } \mathrm{C}_{15: 0}, \\
\quad \text { iso- } \mathrm{C}_{17: 1} \omega 9 c^{\star}\end{array}$ \\
\hline $\begin{array}{l}\text { Major hydroxy fatty } \\
\operatorname{acid}(s)\end{array}$ & $\begin{array}{l}\mathrm{C}_{10: 0} 3-\mathrm{OH}, \mathrm{C}_{12: 0} \\
3-\mathrm{OH} \text {, iso- } \mathrm{C}_{11: 0} 3-\mathrm{OH}\end{array}$ & $\begin{array}{r}\mathrm{C}_{10: 0} 3-\mathrm{OH}, \mathrm{C}_{12: 0} 3- \\
\mathrm{OH}, \text { iso- } \mathrm{C}_{11: 0} 3-\mathrm{OH}\end{array}$ & $\begin{array}{l}\text { iso- } \mathrm{C}_{11: 0} \\
3-\mathrm{OH}^{*}\end{array}$ & iso- $\mathrm{C}_{11: 0} 3-\mathrm{OH}^{*}$ & $\begin{array}{l}\text { iso- } \mathrm{C}_{11: 0} \\
3-\mathrm{OH}^{*}\end{array}$ & iso- $\mathrm{C}_{11: 0} 3-\mathrm{OH}^{*}$ & $\begin{array}{l}\text { iso- } \mathrm{C}_{11: 0} \\
3-\mathrm{OH}^{*}\end{array}$ & $\begin{array}{r}\text { iso- } \mathrm{C}_{11: 0} \\
3-\mathrm{OH}^{*}\end{array}$ & $\begin{array}{l}\text { iso- } \mathrm{C}_{11: 0} \\
3-\mathrm{OH}^{*}\end{array}$ \\
\hline Major polar lipids $§$ & PE, PG, PS, AL & PE, PG, PS, AL & $\mathrm{PE}, \mathrm{PG}^{*}$ & $\mathrm{PE}, \mathrm{PG}^{*}$ & $\mathrm{PE}, \mathrm{PG}^{*}$ & $P E, P G^{*}$ & ND & ND & ND \\
\hline $\begin{array}{l}\text { DNA G }+C \text { content } \\
(\mathrm{mol} \%)\end{array}$ & 48.7 & 49.0 & 57.7 & 59.0 & $58.9^{*}$ & 59.9 & 57.7 & $55.2-55.3$ & $56.0-56.2$ \\
\hline $\begin{array}{l}\text { 16S rRNA gene sequence } \\
\text { similarity to strain } \\
\text { Ni- } 2088^{\mathrm{T}}(\%)\end{array}$ & 100 & 99.3 & 94.9 & 94.0 & 95.1 & 97.6 & 94.5 & 95.1 & 96.5 \\
\hline
\end{tabular}

${ }^{\star}$ Determined in this study for the type strain.

$\dagger$ Data from: $a$, Miyazaki et al. (2008); $b$, Yoon et al. (2003a).

¥Incubation time was extended to $24 \mathrm{~h}$ in this study.

\$AL, Unidentified aminolipid; PE, phosphatidylethanolamine; PG, phosphatidylglycerol; PS, phosphatidylserine. 
although, on a few plates, coccoid cells withstood heat treatment, showing that the heat resistance of coccoid cells was lost with age. In contrast to coccoid cells, the very few rod cells that had remained unconverted in a 1- to 2-week plate culture became even more scarce after being kept for at least 8 months. The coccoid cells of the four Microbulbifer reference strains that were tested were viable after at least 4 months. Based on the observations that almost all rod cells converted to coccoid cells and that only coccoid cells survived for extended periods, it is considered that the coccoid-ovoid cells are a resting form of these organisms, probably playing a survival role in the life cycle.

While the conversion frequency from rod to resting coccoid cells is almost $100 \%$ in the isolates and Microbulbifer reference strains, conversion from vegetative to resting cells in other bacteria is usually low and indefinite: less than $0.1 \%$ in Azotobacter cysts (Sadoff, 1975), 5-95\% in Methylosinus exospores (Whittenbury et al., 1970), 3-95\% in Methylocystis lipid cysts (Whittenbury et al., 1970) and $<5$ to $30 \%$ in Bdellovibrio bdellocysts (Tudor \& Conti, 1977). In Myxococcus myxospores, Dworkin (1996) reported a lowered rate due to autolysis of 65 to $90 \%$ of the vegetative cells during the process of aggregation and early mount formation. The coccoidovoid cells of strains $\mathrm{Ni}-2088^{\mathrm{T}}$ and $\mathrm{F}-104^{\mathrm{T}}$ withstood heat treatment for $10 \mathrm{~min}$ at 75 and $70{ }^{\circ} \mathrm{C}$, respectively, while the rod cells of both strains withstood $55^{\circ} \mathrm{C}$ for $10 \mathrm{~min}$. The heat resistance of the coccoid cells of all four Microbulbifer reference strains tested was $70{ }^{\circ} \mathrm{C}$ and that of rod cells was $55^{\circ} \mathrm{C}$ for M. maritimus JCM $12187^{\mathrm{T}}$ and $50{ }^{\circ} \mathrm{C}$ for the other three strains. The heat resistance of the coccoid cells of the new isolates and Microbulbifer reference strains is comparable to that of the resting cells of other bacteria: Azotobacter cysts $\left(57^{\circ} \mathrm{C}, 15 \mathrm{~min}\right.$; Socolofsky \& Wyss, 1962), Azospirillum cysts $\left(50-60{ }^{\circ} \mathrm{C}, 20 \mathrm{~min}\right.$; Sadasivan \& Neyra, 1987), lipid cysts and Azotobacter-type cysts of Methylocystis (non-viable at $65{ }^{\circ} \mathrm{C}, 30 \mathrm{~min}$; Whittenbury et al., 1970), Methylosoma cysts $\left(60-70{ }^{\circ} \mathrm{C}\right.$, 10 min; Rahalkar et al., 2007), Myxococcus myxospores (killed slowly at $60{ }^{\circ} \mathrm{C}$; Sudo \& Dworkin, 1969) and Bdellovibrio bdellocysts $\left(60{ }^{\circ} \mathrm{C}, 15 \mathrm{~min}\right.$; Tudor \& Conti, 1977). The difference in heat resistance $\left(15-20{ }^{\circ} \mathrm{C}\right)$ between the coccoid and rod cells of the isolates and Microbulbifer reference strains is also comparable to the differences between the cysts and vegetative rod cells of other bacteria, including Azotobacter cysts $\left(3{ }^{\circ} \mathrm{C}\right.$; Socolofsky \& Wyss, 1962), Azospirillum cysts $\left(<10^{\circ} \mathrm{C}\right.$; Sadasivan \& Neyra, 1987), Methylosoma cysts ( $<10{ }^{\circ} \mathrm{C}$; Rahalkar et al., 2007) and Bdellovibrio bdellocysts (about $15{ }^{\circ} \mathrm{C}$; Tudor \& Conti, 1977). The higher heat resistance of coccoid cells over vegetative rod cells probably results from some structural component(s) of the coccoid cells, which may confer the ability to survive for extended periods. The role of coccoid cells in the life cycle appears to be survival during nutrient starvation, since the isolates do not require the ability to survive higher temperatures and desiccation stress in their marine niches. This cycle of stages of vegetative rod and resting coccoid cells in association with the growth phase is the first such description in bacteria.

In addition to coccoid-ovoid cells, the formation of spherical bodies was observed in older cultures of the isolates. To observe spherical bodies, a drop of $75 \%$ ASW was added to growth on an agar medium film of 1/10 MA that had incubated for 2 days. The slide was then covered with a coverslip and incubated for a further $24 \mathrm{~h}$. Spherical bodies were also observed in cultures grown on MA and negatively stained with uranyl acetate. These were mostly formed at the tips of rod cells, were completely spherical when detached and had a smooth surface (Fig. 2o and Supplementary Fig. S5). Spherical bodies were occasionally ruptured in older cultures. There was a higher frequency of spherical bodies when isolates were grown on MA or in $\mathrm{MB}$ at $30{ }^{\circ} \mathrm{C}$ than on $1 / 10 \mathrm{MA}$ at $20-25{ }^{\circ} \mathrm{C}$, and their formation seemed to be enhanced under reduced aerobic conditions. Their size varied, but was generally greater than that of the coccoid cells, being $0.75-2.5 \mu \mathrm{m}$ in diameter. The viability of spherical bodies remains unclear. Spherical bodies were also formed by the Microbulbifer reference strains (Supplementary Fig. S3i). They seem to have been formed by bulging out of the tips or other portions of rod cells. It appeared that the cell surface integrity was weakened in portions of the older rod cells and that these portions became swollen by internal cytoplasmic pressure. Formation of coccoid bodies, spherical bodies, spherical forms or round bodies in older cultures has been reported for various Gram-negative bacteria (Krieg, 1976, 1984). They exhibited unusual features: an unusual method of formation in 'Spirillum lunatum' (Williams \& Rittenberg, 1956) and 'Spirillum serpens' (Aquaspirillum serpens; Terasaki, 1970), loss of viability in 'Desulfovibrio aestuarii' (Desulfovibrio desulfuricans subsp. aestuarii; Levin \& Vaughn, 1968) and Vibrio sp. (Baker \& Park, 1975), loss or degradation of peptidoglycans in 'Spirillum itersonii' (Aquaspirillum itersonii subsp. itersonii; Clark-Walker, 1969) and Vibrio sp. (Baker \& Park, 1975) and association with aberrations in cell division and cell-wall formation (Felter et al., 1969). The spherical bodies observed here in the new isolates and Microbulbifer reference strains are considered to be allied to these forms and are an aberrant form that does not constitute a stage in the life cycle.

Isoprenoid quinones extracted from cells grown in $\mathrm{MB}$ at $30{ }^{\circ} \mathrm{C}$ for $24 \mathrm{~h}$ were analysed according to the LC/MS method described by Nishijima et al. (1997). To investigate the cellular fatty acid composition, cells of the new isolates and reference strains were grown on MA plates at $25{ }^{\circ} \mathrm{C}$ for 2 days. Cellular fatty acid methyl esters were prepared and analysed by gas chromatography (HP6890 series GC system; Hewlett Packard) according to the instructions given for the MIDI Microbial Identification system. For the analysis of polar lipids, cells were grown in $\mathrm{MB}$ at $25^{\circ} \mathrm{C}$ for $24 \mathrm{~h}$ with shaking on a reciprocal shaker. Polar lipids were extracted according to the method described by Minnikin et al. (1984). The two-dimensional TLC method described 
by Komagata \& Suzuki (1987) was performed to separate the polar lipid components, which were then identified on a chromatogram after detection using specific reagents: iodine vapour (total lipids), Dittmer-Lester reagent (phosphate), ninhydrin (free amino groups), periodateSchiff reagent ( $\alpha$-glycols), Dragendorff reagent (quaternary nitrogen) and anisaldehyde/sulphuric acid (glycolipids).

The major respiratory quinone system of all the isolates was ubiquinone-8 (Q-8; 75-95\% peak ratio of the total), with Q-7 and Q-9 as minor components. The cellular fatty acid compositions of strains $\mathrm{Ni}-2088^{\mathrm{T}}$ and $\mathrm{F}-104^{\mathrm{T}}$ and the type strains of described Microbulbifer species are shown in Supplementary Table S2. Considerable differences in the fatty acid profiles were recognized between the new isolates and the seven Microbulbifer type strains. The new isolates possessed $\mathrm{C}_{18: 1} \omega 7 c$ and $\mathrm{C}_{16: 0}$ as the predominant fatty acids. The hydroxy acids that occurred in larger amounts were $\mathrm{C}_{10: 0} 3-\mathrm{OH}, \mathrm{C}_{12: 0} 3-\mathrm{OH}$ and iso- $\mathrm{C}_{11: 0}$ 3-OH. In contrast, the Microbulbifer reference strains have iso- $\mathrm{C}_{15: 0}$ in common as one of the major fatty acids, $\mathrm{C}_{12: 0} 3-\mathrm{OH}$ is not present and iso- $\mathrm{C}_{11: 0} 3-\mathrm{OH}$ is present in larger amounts than in the new isolates. The differences in fatty acid composition between the new isolates and the Microbulbifer reference strains are exemplified by a dendrogram obtained by cluster analysis of fatty acid compositions (Supplementary Fig. S6). The new isolates and the Microbulbifer reference strains examined shared the major polar lipids phosphatidylethanolamine and phosphatidylglycerol, but the new isolates differed from the Microbulbifer species in possessing phosphatidylserine and an unidentified aminolipid (Supplementary Fig. S7).

For determination of the $\mathrm{G}+\mathrm{C}$ content of the DNA and DNA-DNA hybridization experiments, genomic DNA was extracted and purified according to the combined methods of Marmur (1961) and Saito \& Miura (1963). The genomic DNA was digested to nucleotides with nuclease P1 using a DNA-GC kit (Seikagaku Kogyo) according to the procedures described by Katayama-Fujimura et al. (1984). The $\mathrm{G}+\mathrm{C}$ content of the DNA was determined by HPLC with a Develosil ODS-HG-5 column $(4.6 \times 250 \mathrm{~mm}$; Nomura Chemical) and a UV 8010 detector (Tosoh) at $270 \mathrm{~nm}$. DNA-DNA relatedness was determined by the fluorometric hybridization method on microdilution plates (Ezaki et al., 1989). The G $+\mathrm{C}$ content of the DNA of the 15 isolates fell into a narrow range of $48.1-49.7 \mathrm{~mol} \%$ (Supplementary Table S3), differing from the values of 55.2-59.9 mol\% reported for Microbulbifer species (González et al., 1997; Yoon et al., 2003a, 2004, 2007; Miyazaki et al., 2008; the value for M. elongatus ATCC $10144^{\mathrm{T}}$ was $58.9 \mathrm{~mol} \%$, as determined in this study). The DNA-DNA relatedness between strain $\mathrm{Ni}-2088^{\mathrm{T}}$ and the other pelagiomicin-producing strains ranged from 77 to $96 \%$, while the relatedness between strain $\mathrm{F}-104^{\mathrm{T}}$ and the pelagiomicin-producing strains ranged from 6 to $27 \%$ (Supplementary Table S3). This indicates that the pelagiomicin-producing strains constitute a single genomic species and that strain $\mathrm{F}-104^{\mathrm{T}}$ represents a separate genomic species.

The isolates shared almost identical characteristics and differed from described Microbulbifer species in the $\mathrm{G}+\mathrm{C}$ content of the DNA (6-11 mol\% different from the Microbulbifer species; Table 1), major cellular fatty acids and hydroxy fatty acids (Supplementary Table S2) and polar lipid composition (Supplementary Fig. S7). All the Microbulbifer species were similar in these traits. With the exception of $M$. thermotolerans and $M$. maritimus, this group corresponded to the phylogenetic cluster in the Microbulbifer clade obtained by sequence analysis of the $16 \mathrm{~S}$ rRNA gene and concatenated gyrB and ftsZ genes. $M$. thermotolerans and $M$. maritimus formed a cluster with the new isolates and not with the Microbulbifer species in the phylogenetic tree based on $16 \mathrm{~S}$ rRNA gene sequences, with a bootstrap value of $100 \%$ (Fig. 1). The position of $M$. maritimus was indefinite in the phylogenetic clustering based on concatenated gyrB and $f t s Z$ gene sequences (Supplementary Fig. S1). Although inconsistency amongst phylogenetic, genomic and chemotaxonomic traits has been recognized within the members of the Microbulbifer clade, we propose that the new isolates be placed in the genus Microbulbifer on the basis of phylogenetic affiliation, general accordance of taxonomic features and the possession of a vegetative rod and resting coccoid cell cycle.

The 16S rRNA gene sequence similarity, which was less than $98 \%$ between the new isolates and Microbulbifer species (93.6-97.6\%), and the differences in DNA G + C content $(6-11 \mathrm{~mol} \%)$ exclude the assignment of the isolates to any of the extant species of this genus (Vandamme et al., 1996; Stackebrandt \& Goebel, 1994; Stackebrandt, 2006; Trüper \& Schleifer, 2006). The 14 pelagiomicin-producing isolates constituted a single novel species based on the observations that they shared almost identical physiological, biochemical and chemotaxonomic characteristics and a high level of DNA-DNA relatedness. Strain $\mathrm{F}-104^{\mathrm{T}}$ exhibited phenotypic features similar to those of the pelagiomicin-producing strains, but represents a distinct species showing low DNA-DNA relatedness (Supplementary Table S3). The phenotypic features that differ between these two species are the colour of the colonies, production of a water-soluble yellow-green pigment, aesculin hydrolysis, PNPG test, assimilation of acetate and L-arginine and $\alpha$-mannosidase activity (Table 1; see species descriptions). The new isolates showed $16 \mathrm{~S}$ rRNA gene sequence similarity to other gammaproteobacteria of less than $91 \%$ and can be distinguished from other aerobic marine gammaproteobacteria by a combination of cell morphology, motility and flagellation, respiratory quinones, major fatty acid composition, polar lipid composition and DNA G+C content. Another distinguishing feature of these isolates is the possession of a vegetative rod-resting coccus cell cycle. Based on phylogenetic, genetic and chemotaxonomic data, the possession of a vegetative rod cell and resting coccus cell cycle and other phenotypic features, we propose to 
include the 15 isolates in two novel species of the genus Microbulbifer, named Microbulbifer variabilis sp. nov. for the pelagiomicin-producing bacteria and Microbulbifer epialgicus sp. nov. for the UVAS-producing bacterial strain $\mathrm{F}-104^{\mathrm{T}}$.

\section{Description of Microbulbifer variabilis sp. nov.}

Microbulbifer variabilis (va.ri.a.bi'lis. L. masc. adj. variabilis changeable, variable, referring to the change of cell shape in the cell cycle).

Cells are Gram-negative, strictly aerobic, non-motile and non-spore-forming. Catalase- and oxidase-positive. Colonies on MA are irregular (young cultures), rhizoid (older cultures), umbonate, glossy and transparent (young cultures) to opaque (older cultures). Colour of colonies is milky white (young cultures) and yellow-green in the central portion (older cultures). Colonies on 1/10 MA are very thin and spreading. Produces water-soluble yellowgreen pigment on $\mathrm{MA}$ and in MB. Does not produce fluorescent pigment on King's B medium. The organism possesses a rod-coccus cell cycle in association with the growth phase; cells are straight, slender, flexible rods in young cultures, and all convert to coccoid-ovoid cells when proliferation ceases by successive division and a probable simultaneous fragmentation of rod cells and rounding of each unit. Coccoid-ovoid cells are arranged in orderly chains, and revert to the rod form when transferred to fresh medium. The coccoid-ovoid cells are optically dense and have a coarse surface. They survive for extended periods and are considered to be a resting form. Spherical bodies (aberrant form) are formed. Rod cells of the type strain are 3.5-13.5 $\mu \mathrm{m}$ long and $0.42-0.63 \mu \mathrm{m}$ wide on $1 /$ $10 \mathrm{MA}$ in young cultures and the coccoid-ovoid cells are $0.40-0.85 \mu \mathrm{m}$ in diameter and $0.6-1.1$ and $0.4-0.5 \mu \mathrm{m}$ along their major and minor axes, respectively, on 1/10 MA in older cultures. Rod cells possess fibrous peritrichous structures on the surface. Slightly halophilic; the range of $\mathrm{NaCl}$ concentration for growth is $0.5-7.0 \%(\mathrm{w} / \mathrm{v}$,$) with$ optimum growth at $2.0 \%(\mathrm{w} / \mathrm{v})$. No growth occurs in the absence of $\mathrm{NaCl}$ or in $7.5 \% \mathrm{NaCl}$. Requires $\mathrm{Na}^{+}$and a bivalent cation, $\mathrm{Mg}^{2+}$ or $\mathrm{Ca}^{2+}$, for growth. Growth occurs at $12-42{ }^{\circ} \mathrm{C}$, with an optimum of $30{ }^{\circ} \mathrm{C}$, but not at 5 or $45{ }^{\circ} \mathrm{C}$. Growth occurs at $\mathrm{pH} 6.0-9.0$ and optimally at $\mathrm{pH} 7.5-8.0$, but not at $\mathrm{pH} 5.5$ or 9.5. Uses ammoniacal nitrogen; does not require growth factors and does not grow anaerobically in the presence of nitrate. Polyhydroxybutyrate is not accumulated. Nitrate reduction and PNPG tests are positive. Starch, gelatin, casein, DNA, Tween 80, aesculin and lecithin are hydrolysed. Agar and chitin are not hydrolysed. Negative for arginine dihydrolase, citrate utilization, urease, $\mathrm{H}_{2} \mathrm{~S}$ generation and indole production. D-Glucose, trehalose, cellobiose, methyl $\alpha$-Dglucoside, $\mathrm{N}$-acetyl-D-glucosamine, starch, acetate, propionate, L-alanine, L-glutamate, L-asparagine and L-arginine are used. L-Arabinose, D-xylose, D-fructose, Dgalactose, sucrose, lactose, melezitose, glycerol, D-sorbitol, D-mannitol, myo-inositol, dulcitol, formate, fumarate, DL- malate, malonate, succinate, citrate, gluconate, alginate, benzoate and DL-serine are not used. Mannose and maltose are used variably. Tests for the following enzymes are positive with the API ZYM gallery: alkaline phosphatase, esterase (C4), esterase lipase (C8), lipase (C14), leucine arylamidase, valine arylamidase, trypsin, acid phosphatase, naphthol-AS-BI-phosphohydrolase, $N$-acetyl- $\beta$-glucosaminidase and $\alpha$-glucosidase. The major respiratory quinone is ubiquinone-8. The major cellular fatty acids are $\mathrm{C}_{18: 1} \omega 7 \mathrm{c}$ and $\mathrm{C}_{16: 0}$. Hydroxy fatty acids are $\mathrm{C}_{10: 0} 3-\mathrm{OH}, \mathrm{C}_{12: 0} 3-$ $\mathrm{OH}$ and iso- $\mathrm{C}_{11: 0} 3-\mathrm{OH}$. The major polar lipids are phosphatidylethanolamine, phosphatidylglycerol and phosphatidylserine. The $\mathrm{G}+\mathrm{C}$ content of the DNA is 48.1-49.7 mol\%.

The type strain is $\mathrm{Ni}-2088^{\mathrm{T}}\left(=\mathrm{MBIC} 01082^{\mathrm{T}}=\mathrm{ATCC}\right.$ $\left.700307^{\mathrm{T}}\right)$. The type strain and 13 other strains were isolated from the surfaces of green, brown and red algae, a cyanobacterium and seagrass, collected in tropical and subtropical areas (Palau, Yap and Ishigaki Jima) in the Pacific Ocean.

\section{Description of Microbulbifer epialgicus sp. nov.}

Microbulbifer epialgicus (e.pi.al'gi.cus. Gr. prep. epi upon; N.L. masc. adj. algicus pertaining to water plants, to algae; N.L. masc. adj. epialgicus living on algae).

Cells are Gram-negative, strictly aerobic, non-motile and non-spore-forming. Catalase- and oxidase-positive. Colonies on MA are irregular (young cultures), convex, glossy, transparent to opaque (older cultures). Colour of colonies is pale brown, becoming browner in the central portion of older cultures. Colonies on 1/10 MA are very thin and spreading. Fluorescent pigment is not produced on King's B medium. The organism possesses a rod-coccus cell cycle in association with the growth phase; cells are straight, slender, flexible rods in young cultures, and all convert to coccoid-ovoid cells when proliferation ceases by successive division and a probable simultaneous fragmentation of rod cells and rounding of each unit. Coccoidovoid cells are arranged in orderly chains, and revert to the rod form when transferred to fresh medium. Coccoidovoid cells are optically dense and have a coarse surface. They survive for extended periods and are considered to be a resting form. Spherical bodies (aberrant form) are formed. The rod cells of the type strain are 3.0-13.5 $\mu \mathrm{m}$ long and $0.35-0.65 \mu \mathrm{m}$ wide on $1 / 10 \mathrm{MA}$ in young cultures and the coccoid-ovoid cells are $0.45-1.10 \mu \mathrm{m}$ in diameter and $0.75-1.10$ and $0.40-0.75 \mu \mathrm{m}$ along their major and minor axes, respectively, on 1/10 MA in older cultures. The rod cells possess fibrous peritrichous structures on the surface. Slightly halophilic; the range of $\mathrm{NaCl}$ concentrations for growth is $0.5-6.5 \%(\mathrm{w} / \mathrm{v})$ with an optimum of $2.0 \%$. Does not grow in the absence of $\mathrm{NaCl}$ or in $7.0 \%$ $\mathrm{NaCl}$. Requires $\mathrm{Na}^{+}$and a bivalent cation, $\mathrm{Mg}^{2+}$ or $\mathrm{Ca}^{2+}$, for growth. Growth occurs at $10-40{ }^{\circ} \mathrm{C}$ with an optimum of $30{ }^{\circ} \mathrm{C}$, but not at 5 or $45{ }^{\circ} \mathrm{C}$. It grows at $\mathrm{pH} 6.0-9.0$ and optimally at $\mathrm{pH} 7.0-8.0$, but not at $\mathrm{pH} 5.5$ or 9.5. Cells use 
ammoniacal nitrogen; does not require growth factors and does not grow anaerobically in the presence of nitrate. Polyhydroxybutyrate is not accumulated. Nitrate is reduced. Starch, gelatin, casein, DNA, Tween 80 and lecithin are hydrolysed. Agar, chitin and aesculin are not hydrolysed. Negative for arginine dihydrolase, citrate utilization, urease, indole production and PNPG test. DGlucose, mannose, trehalose, cellobiose, methyl $\alpha$-Dglucoside, $N$-acetyl-D-glucosamine, starch, propionate, L-alanine, L-glutamate and L-asparagine are used. LArabinose, D-xylose, D-fructose, D-galactose, maltose, sucrose, lactose, melezitose, glycerol, D-sorbitol, D-mannitol, myo-inositol, dulcitol, formate, acetate, fumarate, DLmalate, malonate, succinate, citrate, alginate, benzoate, gluconate, DL-serine and L-arginine are not used. Tests for the following enzymes are positive with the API ZYM gallery: alkaline phosphatase, esterase (C4), esterase lipase (C8), lipase (C14), leucine arylamidase, valine arylamidase, cystine arylamidase (weak), trypsin, acid phosphatase, naphthol-AS-BI-phosphohydrolase, $N$-acetyl- $\beta$-glucosaminidase, $\alpha$-glucosidase and $\alpha$-mannosidase. The major respiratory quinone is ubiquinone-8. The major cellular fatty acids are $\mathrm{C}_{18: 1} \omega 7 c$ and $\mathrm{C}_{16: 0}$. Hydroxy fatty acids are $\mathrm{C}_{10: 0} 3-\mathrm{OH}, \mathrm{C}_{12: 0} 3-\mathrm{OH}$ and iso- $\mathrm{C}_{11: 0} 3-\mathrm{OH}$. Major polar lipids are phosphatidylethanolamine, phosphatidylglycerol and phosphatidylserine. The $\mathrm{G}+\mathrm{C}$ content of the DNA of the type strain is $49 \mathrm{~mol} \%$.

The type strain is $\mathrm{F}-104^{\mathrm{T}}\left(=\mathrm{MBIC} 03330^{\mathrm{T}}=\mathrm{DSM} 18651^{\mathrm{T}}\right)$, isolated from the surface of a green alga collected on the seashore in Palau in the Pacific Ocean.

\section{Acknowledgements}

This work was supported by the New Energy and Industrial Technology Development Organization of Japan (NEDO). We are grateful to Professor Dr H. G. Trüper for help with the nomenclature of the novel species.

\section{References}

Altschul, S. F., Madden, T. F., Schäffer, A. A., Zhang, J., Zhang, Z., Miller, W. \& Lipman, D. J. (1997). Gapped BLAST and PSI-BLAST: a new generation of protein database search programs. Nucleic Acids Res 25, 3389-3402.

Baker, D. A. \& Park, R. W. A. (1975). Changes in morphology and cell wall structure that occur during growth of Vibrio sp. NCTC4716 in batch culture. J Gen Microbiol 86, 12-28.

Barrow, G. I. \& Feltham, R. K. A. (1993). Cowan and Steel's Manual for the Identification of Medical Bacteria, 3rd edn. Cambridge: Cambridge University Press.

Baumann, P. \& Baumann, L. (1981). The marine Gram-negative eubacteria: genera Photobacterium, Beneckea, Alteromonas, Pseudomonas, and Alcaligenes. In The Prokaryotes, pp. 1302-1331. Edited by M. P. Starr, H. Stolp, H. G. Trüper, A. Balows \& H. G. Schlegel. Berlin: Springer.

Berleman, J. E. \& Bauer, C. E. (2004). Characterization of cyst cell formation in the purple photosynthetic bacterium Rhodospirillum centenum. Microbiology 150, 383-390.
Clark-Walker, G. D. (1969). Association of microcyst formation in Spirillum itersonii with the spontaneous induction of a defective bacteriophage. J Bacteriol 97, 885-892.

Dworkin, M. (1996). Recent advances in the social and developmental biology of the myxobacteria. Microbiol Rev 60, 70-102.

Ezaki, T., Hashimoto, Y. \& Yabuuchi, E. (1989). Fluorometric deoxyribonucleic acid-deoxyribonucleic acid hybridization in microdilution wells as an alternative to membrane filter hybridization in which radioisotopes are used to determine genetic relatedness among bacterial strains. Int J Syst Bacteriol 39, 224-229.

Felsenstein, J. (1985). Confidence limits on phylogenies: an approach using the bootstrap. Evolution 39, 783-791.

Felter, R. A., Colwell, R. R. \& Chapman, G. B. (1969). Morphology and round body formation in Vibrio marinus. J Bacteriol 99, 326-335.

González, J. M., Mayer, F., Moran, M. A., Hodson, R. E. \& Whitman, W. B. (1997). Microbulbifer hydrolyticus gen. nov., sp. nov. and Marinobacterium georgiense gen. nov., sp. nov., two marine bacteria from a lignin-rich pulp mill waste enrichment community. Int J Syst Bacteriol 47, 369-376.

Hall, T. A. (1999). BioEdit: a user-friendly biological sequence alignment editor and analysis program for Windows 95/98/NT. Nucleic Acids Symp Ser 41, 95-98.

Hanzawa, N., Kanai, S., Kastuta, A., Nakagawa, Y. \& Yamasato, K. (1995). 16S rDNA-based phylogenetic analysis of marine flavobacteria. J Mar Biotechnol 3, 111-114.

Heulin, T., Barakat, M., Christen, R., Lesourd, M., Sutra, L., De Luca, G. \& Achouak, W. (2003). Ramlibacter tataouinensis gen. nov., sp. nov., and Ramlibacter henchirensis sp. nov., cyst-producing bacteria isolated from subdesert soil in Tunisia. Int J Syst Evol Microbiol 53, 589-594.

Hoeniger, J. F. M., Ladwig, R. \& Moor, H. (1972). The fine structure of "resting bodies" of Bdellovibrio sp. strain W developed in Rhodospirillum rubrum. Can J Microbiol 18, 87-92.

Humm, H. J. (1946). Marine-agar digesting bacteria of the South Atlantic coast. Duke Univ Mar Stn Bull 3, 45-75.

Imamura, N., Nishijima, M., Takadera, T., Adachi, K., Sakai, M. \& Sano, H. (1997). New anticancer antibiotics pelagiomicins, produced by a new marine bacterium Pelagiobacter variabilis. J Antibiot (Tokyo) 50, 8-12.

Katayama-Fujimura, Y., Komatsu, Y., Kuraishi, H. \& Kaneko, T. (1984). Estimation of DNA base composition by high performance liquid chromatography of its nuclease P1 hydrolysate. Agric Biol Chem 48, 3169-3172.

Kawasaki, H., Hoshino, Y., Kuraishi, H. \& Yamasato, K. (1992). Rhodocista centenaria gen. nov., sp. nov., a cyst-forming anoxygenic photosynthetic bacterium and its phylogenetic position in the Proteobacteria alpha group. J Gen Appl Microbiol 38, 541-551.

Komagata, K. \& Suzuki, K. (1987). Lipid and cell-wall analysis in bacterial systematics. Methods Microbiol 19, 161-207.

Krieg, N. R. (1976). Biology of the chemoheterotrophic spirilla. Bacteriol Rev 40, 55-115.

Krieg, N. R. (1984). Aerobic/microaerophic, motile, helical/vibrioid Gram-negative bacteria. In Bergey's Manual of Systematic Bacteriology, vol. 1, pp. 71-124. Edited by N. R. Krieg \& J. G. Holt. Baltimore: Williams \& Wilkins.

Kumar, S., Tamura, K. \& Nei, M. (2004). MEGA3: integrated software for molecular evolutionary genetics analysis and sequence alignment. Brief Bioinform 5, 150-163.

Levin, R. E. \& Vaughn, R. H. (1968). Spontaneous spheroplast formation by Desulfovibrio aestuarii. Can J Microbiol 14, 1271-1276. 
Marmur, J. (1961). A procedure for the isolation of deoxyribonucleic acid from microorganisms. J Mol Biol 3, 208-218.

Minnikin, D. E., O'Donnell, A. G., Goodfellow, M., Alderson, G., Athalye, M., Schaal, A. \& Parlett, J. H. (1984). An integrated procedure for the extraction of bacterial isoprenoid quinones and polar lipids. J Microbiol Methods 2, 233-241.

Miyazaki, M., Nogi, Y., Ohta, Y., Hatada, Y., Fujiwara, Y., Ito, S. \& Horikoshi, K. (2008). Microbulbifer agarilyticus sp. nov. and Microbulbifer thermotolerans sp. nov., agar-degrading bacteria isolated from deep-sea sediment. Int J Syst Evol Microbiol 58, 1128-1133.

Nagao, T., Adachi, K., Nishida, F., Nishijima, M. \& Mochida, K. (2000). Butyl and octyl 3-acetamido-4-hydroxybenzoate as fat-soluble UV absorbers, and their manufacture with Pelagiobacter species. Japanese patent no. 2000016976.

Nishijima, M., Araki-Sakai, M. \& Sano, H. (1997). Identification of isoprenoid quinones by frit-FAB liquid chromatography-mass spectrometry for the chemotaxonomy of microorganisms. J Microbiol Methods 28, 113-122.

Palleroni, N. J. (1984). Genus Pseudomonas Migula 1894. In Bergey's Manual of Systematic Bacteriology, vol. 1, pp. 141-199. Edited by N. R. Krieg \& J. G. Holt. Baltimore: Williams \& Wilkins.

Rahalkar, M., Bussman, I. \& Schink, B. (2007). Methylosoma difficile gen. nov., sp. nov., a novel methanotroph enriched by gradient cultivation from littoral sediment of Lake Constance. Int J Syst Evol Microbiol 57, 1073-1080.

Reichenbach, H. (1992). The order Cytophagales. In The Prokaryotes, 2nd edn, vol. 4, pp. 3631-3675. Edited by A. Balows, H. G. Trüper, M. Dworkin, W. Harder \& K. H. Schleifer. New York: Springer.

Reichenbach, H. \& Dworkin, M. (1992). The myxobacteria. In The Prokaryotes, 2nd edn, vol. 4, pp. 3416-3487. Edited by A. Balows, H. G. Trüper, M. Dworkin, W. Harder \& K. H. Schleifer. New York: Springer.

Romanenko, L. A., Schumann, P., Zhukova, N. V., Rohde, M., Mikhailov, V. V. \& Stackebrandt, E. (2003). Oceanisphaera litoralis gen. nov., sp. nov., a novel halophilic bacterium from marine bottom sediments. Int J Syst Evol Microbiol 53, 1885-1888.

Sadasivan, L. \& Neyra, C. A. (1985). Flocculation in Azospirillum brasilense and Azospirillum lipoferum: exopolysaccharides and cyst formation. J Bacteriol 163, 716-723.

Sadasivan, L. \& Neyra, C. A. (1987). Cyst production and brown pigment formation in aging cultures of Azospirillum brasilense ATCC 29145. J Bacteriol 169, 1670-1677.

Sadoff, H. L. (1975). Encystment and germination in Azotobacter vinelandii. Bacteriol Rev 39, 516-539.

Saito, H. \& Miura, K. (1963). Preparation of transforming deoxyribonucleic acid by phenol treatment. Biochim Biophys Acta 72, 619-629.

Saitou, N. \& Nei, M. (1987). The neighbor-joining method: a new method for reconstructing phylogenetic trees. Mol Biol Evol 4, 406425.
Socolofsky, M. D. \& Wyss, O. (1962). Resistance of the Azotobacter cyst. J Bacteriol 84, 119-124.

Stackebrandt, E. (2006). Defining taxonomic ranks. In The Prokaryotes. A Handbook on the Biology of Bacteria, 3rd edn, vol. 1, pp. 29-57. Edited by M. Dworkin, S. Falkow, E. Rosenberg, K. H. Schleifer \& E. Stackebrandt. New York: Springer.

Stackebrandt, E. \& Goebel, B. M. (1994). Taxonomic note: a place for DNA-DNA reassociation and $16 \mathrm{~S}$ rRNA sequence analysis in the present species definition in bacteriology. Int J Syst Bacteriol 44, 846849.

Sudo, S. Z. \& Dworkin, W. (1969). Resistance of vegetative cells and microcysts of Myxococcus xanthus. J Bacteriol 98, 883-887.

Terasaki, Y. (1970). Some observations on the life history of Spirillum serpens. Bull Suzugamine Women's Coll Nat Sci 15, 9-17.

Thompson, J. D., Higgins, D. G. \& Gibson, T. J. (1994). CLUSTAL W: improving the sensitivity of progressive multiple sequence alignment through sequence weighting, position-specific gap penalties and weight matrix choice. Nucleic Acids Res 22, 4673-4680.

Trüper, H. G. \& Schleifer, K. H. (2006). Prokaryote characterization and identification. In The Prokaryotes. A Handbook on the Biology of Bacteria, 3rd edn, vol. 1, pp. 58-79. Edited by M. Dworkin, S. Falkow, E. Rosenberg, K. H. Schleifer \& E. Stackebrandt. New York: Springer.

Tudor, J. J. \& Conti, S. F. (1977). Characterization of bdellocysts of Bdellovibrio sp. J Bacteriol 131, 314-322.

Vandamme, P., Pot, B., Gillis, M., De Vos, P., Kersters, K. \& Swings, J. (1996). Polyphasic taxonomy: a consensus approach to bacterial systematics. Microbiol Rev 60, 407-438.

Whittenbury, R., Davis, S. L. \& Davey, J. F. (1970). Exospores and cysts formed by methane-utilizing bacteria. J Gen Microbiol 61, 219-226.

Williams, M. A. \& Rittenberg, S. C. (1956). Microcyst formation and germination in Spirillum lunatum. J Gen Microbiol 15, 205-209.

Yamamoto, S. \& Harayama, S. (1995). PCR amplification and direct sequencing of $g y r B$ genes with universal primers and their application to the detection and taxonomic analysis of Pseudomonas putida strains. Appl Environ Microbiol 61, 1104-1109.

Yoon, J.-H., Kim, I.-G., Shin, D.-Y., Kang, K. H. \& Park, Y.-H. (2003a). Microbulbifer salipaludis sp. nov., a moderate halophile isolated from a Korean salt marsh. Int J Syst Evol Microbiol 53, 53-57.

Yoon, J.-H., Kim, H., Kang, K. H., Oh, T.-K. \& Park, Y.-H. (2003b). Transfer of Pseudomonas elongata Humm 1946 to the genus Microbulbifer as Microbulbifer elongatus comb. nov. Int J Syst Evol Microbiol 53, 1357-1361.

Yoon, J.-H., Kim, I.-G., Oh, T.-K. \& Park, Y.-H. (2004). Microbulbifer maritimus sp. nov., isolated from an intertidal sediment from the Yellow Sea, Korea. Int J Syst Evol Microbiol 54, 1111-1116.

Yoon, J.-H., Jung, S.-Y., Kang, S.-J. \& Oh, T.-K. (2007). Microbulbifer celer sp. nov., isolated from a marine solar saltern of the Yellow Sea in Korea. Int J Syst Evol Microbiol 57, 2365-2369. 